\title{
EFEKTIVITAS PEMBELAJARAN MATEMATIKA MELALUI PENERAPAN MODEL MEA (MEANS - ENDS - ANALYSIS) PADA SISWA SMP
}

\author{
Muhammad Rizal Usman \\ Universitas Muhammadiyah Makassar, Makassar \\ rizal.usman@unismuh.ac.id
}

\begin{abstract}
Abstrak
Penelitian ini bertujuan untuk mengetahui keefektifan penerapan model MEA (Means Ends - Analysis) dalam pembelajaran matematika pada siswa kelas VIII SMP Negeri 1 Libureng Kabupaten Bone semester ganjil tahun ajaran 2018/2019. Jenis penelitian ini adalah pre - experimental designdengan bentuk one - group pretest - posttest design yang hanya melinatkan satu kelas. Teknik pengambilan sampel pada penelitian ini adalah dengan caracluster random sampling. Instrument penelitian yang digunakan adalah tes hasil belajar, lembar observasi aktivitas siswa, dan angket respons siswa.Analisis data yang digunakan adalah analisis deskriptif. Analisis hasil penelitian menunjukkan bahwa: (1) skor rata - rata hasil belajar matematika siswa sebelum diterapkan model MEA adalah 18.57 dan berada pada kategori sangat rendah dengan standar deviasi 4.47, sedangkan skor rata - rata hasil belajar matematika siswa setelah diterapkan model MEA adalah 80.23 dengan standar deviasi 6.55 dimana skor terendah adalah 62 dan skor tertinggi adalah 94. Dari hasil tersebut diperoleh bahwa 22 siswa atau $84.6 \%$ mencapai ketuntasan individu dan 4 siswa atau $15.4 \%$ tidak mencapai ketuntasan individu. Ini berarti ketuntasan secara klasikal tercapai dengan nilai gain ternormalisasi yaitu 0.7577 berada pada kategori tinggi. (2) aktivitas siswa berada pada kategori baik atau positif dengan rata - rata 86.05\%. (3) angket respons siswa menunjukkan bahwa respons siswa terhadap pembelajaran melalui MEA positif dengan rata - rata $77.5 \%$.
\end{abstract}

Kata Kunci: efektifitas, matematika. Model MEA (Means - Ends - Analysis)

\begin{abstract}
This study aims to determine the effectiveness of the application of the MEA (Means Ends - Analysis) model in mathematics learning in class VIII SMP Negeri 1 Libureng Kabupaten Bone in the odd semester of the 2018/2019 academic year. This type of research is pre-experimental design with the form of one-group pretest - a posttest design that only dissolves one class. The sampling technique in this study was caracluster random sampling. The research instruments used were learning outcomes tests, student activity observation sheets, and student response questionnaires. The data analysis used was descriptive analysis. Analysis of the results showed that: (1) the average score of students 'mathematics learning before the MEA model was 18.57 and was in the very low category with a standard deviation of 4.47 , while the average score of students' mathematics learning after the MEA model was 80.23 with standard deviation 6.55 where the lowest score is 62 and the highest score is 94 . From these results it was found that 22 students or $84.6 \%$ achieved individual completeness and 4 students or $15.4 \%$ did not achieve individual completeness. This means that classical completeness is achieved with the normalized gain value of 0.7577 in the high category. (2) student activities are in the good or positive category with an average of $86.05 \%$. (3) student response questionnaires show that students' responses to learning through MEA are positive with an average of $77.5 \%$.
\end{abstract}

Keywords: effectiveness, mathematics, MEA Model (Means - Ends - Analysis) 


\section{Pendahuluan}

Matematika menjadi salah satu pelajaran yang penting karena matematika sangat berguna dalam membantu manusia dalam kehidupan sehari-hari.Sebagai salah satu pelajaran yang penting di setiap jenjang pendidikan tidak menjadikan matematika sebagai pelajaran yang disukai oleh siswa hal tersebut dikarenakan pada umumnya siswa beranggapan bahwa matematika itu pelajaran yang membosankan, rumit dengan segala rumus yang harus dihafalkan serta beberapa materi yang pengaplikasiannya di kehidupan sehari-hari itu sulit ditemukan. Untuk proses belajar matematika di sekolah formal didukung beberapa komponen salah satunya ialah pembelajaran.

Pembelajaran adalah proses interaksi siswa dengan guru dan sumber belajar pada suatu lingkungan belajar.Interaksi mengandung arti hubungan timbal balik antara guru dan siswa.Interaksi antara siswa, sumber belajar, dan lingkungan sekitar dapat pula terjadi dalam upaya meningkatkan pengalaman belajar.Dalam pembelajaran matematika prestasi siswa khususnya pada jenjang sekolah menengah pertama masih rendah. Hal tersebut sesuai dengan hasil Trends in Mathematics and Science Study (TIMSS) 2015 yang menempatakan Indonesia pada urutan 45 dari 50 negara dengan skor matematika 397 (Kompas.com: 2016).

Rendahnya kemampuan siswa Indonesia dalam pelajaran matematika ini, terjadi pula di SMP Negeri 1Libureng hal ini diperkuat dengan hasil observasi yang dilakukan pada hari kamis tanggal 24 Mei 2018 yaitu keaktifan siswa dalam pembelajaran matematika masih belum terlihat, serta pembelajaran yang hanya berpusat pada guru. Keaktifan siswa dalam kelashanyalah mendengar dan mencatat mereka cenderung malas untuk bertanya tentang materi yang belum dipahami, belum berani menyelesaikan soal di papan tulis. Serta hasil belajar siswa dalam pembelajaran matematika masih rendah dibandingkan dengan mata pelajaran lain, ini berdasarkan nilai rapor siswa pada semester ganjil 2017/2018 yang rata ratanya hanya 75.Permasalahan tersebut mengakibatkan hasil belajar dari siswa masih rendah hal itu terbukti dari hanya 5-8 orang yang nilainya berada diatas KKM (Kriteria Ketuntasan Minimal)

Agar pembelajaran berpusat pada siswa, guru perlu memilih suatu model pembelajaran yang memerlukan keterlibatan siswa secara aktif dan juga dapat mengembangkan kemampuan berpikirnya selama proses belajar mengajar. Salah satu alternatif model pembelajaran tersebut yaitu model MEA (Means - Ends - Analysis). MEA merupakan suatu model untuk menganalisis permasalahan melalui berbagai cara untuk mencapai tujuan akhir yang diinginkan. MEA merupakan model pembelajaran yang 
memisahkan permasalahan yang diketahui dan tujuan yang akan dicapai yang kemudian mengidentifikasi perbedaan serta memilih cara untuk mengurangi perbedaan - perbedaan tersebut. Dalam model pembelajaran MEA ini siswa tidak hanya dinilai pada hasil pengerjaannya, namun juga dinilai pada proses pengerjaannya. Proses pembelajaran seperti ini, diharapkan dapat memberikan pengaruh posotif terhadap keefektifan siswa secara optimal.

Efektivitas berasal dari kata "efektif”. Dalam Kamus Besar Bahasa Indonesia "efektif” berarti : (1) ada efeknya (akibatnya, pengaruhnya, kesannya), (2) dapat membawa hasil, berhasil, berguna. Sedangkan efektivitas berarti : (1) keadaan berpengaruh : hal berkesan, (2) keberhasilan usaha atau tindakan. Menurut Uno dan Nurdin Muhammad (2014:29) pada dasarnya efektivitas ditujukan untuk menjawab pertanyaan seberapa jauh tujuan pembelajaran telah dapat dicapai oleh peserta didik. Menurut Paolini (2015), effective communication is a fundamental component of good teaching, an instructor's communication skills during lesson delivery is a distinguishing factor in student learning outcomes. Yang artinya kominukasi yang efektif adalah komponen dasar dari pengajaran yang baik, keterampilan komunikasi instruktur salama proses pembelajaran merupakan faktor pembeda dalam hasil belajar siswa.

Suatu pembelajaran dikatakan efektif apabila memenuhi persyaratan utama keefektifan pengajaran, yaitu:

1) Presentasi waktu belajar siswa yang tinggi dicurahkan terhadap KBM

2) Rata-rata perilaku melaksanakan tugas yang tinggi di antara siswa.

3) Ketepatan kandungan materi yang ajaran dengan kemampuan siswa (orientasi keberhasilan belajar) diutamakan.

4) Mengembangkan suasana belajar yang akrab dan positif, mengembangkan struktur kelas yang mendukung (2) tanpa mengabaikan butir (4). (Soemosasmito, 1998; 119 dalam Trianto, 2011; 20).

Indikator keefektifan pembelajaran diantaranya

1) Ketuntasan hasil belajar siswa

Menurut Dimayanti dan Mudjiono (dalam Himitsuqalbu, 2015) hasil belajar adalah hasil yang dicapai dalam bentuk angka-angka atau skor setelah diberikan tes hasil belajar pada setiap akhir pembelajaran.Nilai yang diperoleh siswa menjadi acuan untuk melihat penguasaan siswa dalam menerima materi pelajaran. Salah satu penerapan suatu model, pendekatan, dan metode pembelajaran adalah untuk melihat ketercapaian tujuan 
pembelajaran.Ketercapaian tujuan pembelajaran salah satunya dapat dilihat dari ketuntasan hasil belajar yang diukur dengan tes hasil belajar.

Jadi, dapat disimpulkan bahwa ketuntasan hasil belajar adalah tingkat ketercapaian pembelajaran yang dicapai oleh siswa, ketuntasan hasil belajar siswa yang diukur dengan tes hasil belajar. Ketuntasan hasil belajar dapat dilihat dari hasil belajar yang telah mencapai ketuntasan klasikal.

2) Aktivitas siswa dalam mengikuti pembelajaran

Menurut Kamus Besar Bahasa Indonesia, aktivitas artinya adalah "kegiatan/ keaktifan”.Aktivitas siswa adalah kegiatan yang dilakukan siswa selama mengikuti proses belajar mengajar. Tujuan pembelajaran akan tercapai apabila siswa aktif membangun pengetahuannya, karena itu kefektifan juga dipengaruhi oleh aktivitas siswa dalam pembelajaran. Pembelajaran dikatakan efektif apabila siswa secara aktif dilibatkan dalam pengorganisasian dan pengetahuan.

Jadi, dapat disimpulkan bahwa aktivitas belajar adalah segala kegiatan yang dilakukan dalam proses interaksi (guru dan siswa) dalam rangka mencapai tujuan pembelajaran. Aktivitas yang dimaksudkan di sini penekanannya adalah pada siswa, sebab dengan adanya aktivitas siswa dalam proses pembelajaran akan berdampak terciptanya situasi belajar aktif.

3) Respons siswa terhadap pembelajaran

Respons siswa merupakan salah satu kriteria suatu pembelajaran dikatakan efektif atau tidak.Respon siswa di bagi dua, yaitu respons positif dan negatif.Respons siswa yang positif merupakan tanggapan perasaan senang, setuju atau merasakan ada kemajuan setelah pelaksanaan suatu model, pendekatan atau metode pembelajaran.Sedangkan respons negatif adalah sebaliknya.Kriteria respons dikatakan positif dalam penelitian ini adalah apabila siswa yang memberi respons positif lebih banyak dibandingkan dengan siswa yang memberi respons negatif terhadap sejumlah aspek yang ditanyakan.

Secara etimologis, MEA terdiri dari tiga unsur kata yaitu Means, Ends dan Analysis. Means yang berarti cara, Ends yang berarti tujuan, serta Analysis yang berarti menyelidiki dengan sistematis, (Huda, 2016: 294). Secara keseluruhan, model MEA dapat diartikan sebagai suatu model untuk menganalisis permasalahan melalui berbagai cara untuk mencapai tujuan akhir yang diinginkan. Menurut Jeobagio (2017), the application of Means - Ends Analysis strategy as a learning model is one of appropriate solution to problem solving method, MEA model is one solution to the need for innovative learning model currently, combined with value approach expected to help the teacher. Yang 
artinya penerapan strategi Means - Ends Analysis sebagai model pembelajaran adalah salah satu solusi yang tepat untuk metode pemecahan masalah, model MEA merupakan salah satu solusi untuk kebutuhan akan model pembelajaran inovatif saat ini, dikombinasikan dengan pendekatan nilai yang diharapkan dapat membantu guru mata pelajaran.

Model MEA memfokuskan untuk membagi - bagi permasalahan menjadi bagian bagian tertentu dari permasalahan tersebut untuk mencapai tujuan (goal state) yang diinginkan. Untuk mencapai goal state dibutuhkan beberapa tahapan, yakni mengidentifikasi perbedaan antara kondisi saat ini (current state) dan tujuan (goal state), meyususn subtujuan (subgoals) untuk mengurangi perbedaan tersebut, dan memilih operator yang tepat serta mengapliksikannya dengan benar sehingga subgoals yang telah disusun dapat dicapai, (Huda, 2016: 295).

Model MEA merupakan suatu model penyelesaian masalah yang menganalisis permasalahan melalui penyederhanaan masalah dengan mengurangi perbedaan keadaan awal (initial state) dan tujuan (goal state) melalui pembentukan subtujuan (subgoals) sehingga menghasilkan kondisi sekarang (current state). Initial state merupakan informasi - informasi yang terdapat dalam masalah yang dapat membantu penyelesaian masalah.Goal state merupakan hasil akhir yang diinginkan sebagai suatu solusi terhadap permasalahn. Current state merupakan informasi baru yang didapatkan dari hasil perbedaan antara initial state dengan goal state.

Dalam pembelajaran matematika, model MEA bisa diterapkan dengan mengikuti langkah - langkah berikut:

1) Identifikasi Perbedaan Keadaan Awal (Initial State) dan Tujuan (Goal State)

Pada tahap ini, siswa dituntut untuk mampu memahami masalah sehingga dapat mengidentifikasi informasi - informasi yang terdapat dalam masalah, serta permasalahan yang ingin dipecahkan dan kemudian mereduksi perbedaan dari kedua keadaan tersebut.

2) Identifikasi Perbedaan antara Kondisi Sekarang (Current State) dan Tujuan (Goal State)

Pada tahap ini, siswa dituntut untuk memahami dan mengetahui konsep - konsep dasar matematika yang terkandung dalam permasalahan matematika yang diberikan sehingga siswa dapat mengidentifikasi perbedaan antara keadaan sekarang yang merupakan hasil pereduksian dari tahap sebelumnya dan tujuan.

3) Pembentukan Subtujuan (Subgoals) 
Pada tahap ini, siswa diharuskan untuk membentuk subgoals dalam menyelesaikan masalah agar siswa lebih fokus dalam memecahkan masalah secara bertahap hingga tujuan tercapai.

4) Pemilihan Solusi

Pada tahap ini, setelah subgoals terbentuk, pesert didik menyelesaikan permasalahan pada setiap subgoals secara bertahap untuk mengurangi perbedaan tersebut hingga tercapainya tujuan.

\section{Metode Penelitian}

Jenis penelitian yang digunakan adalah penelitian kuantitatif dengan metode penelitian eksperimen yang menggunkan desain penelitian pre - experimental design dengan bentuk one - group pretest - posttest design dimana pada penelitian ini hanya melibatkan kelas eksperimen (percobaan) dengan melakukan tes awal (pretest).Pada desain ini terdapat pretest, sebelum diberi perlakuan.Dengan demikian hasil perlakuan dapat diketahui lebih akurat, karena dapat membandingkan dengan keadaan sebelum di beri perlakuan. Desain ini dapat digambarkan sebagai berikut:

$$
\begin{aligned}
& \mathrm{O}_{1} \mathrm{X} \mathrm{O}_{2} \\
& \mathrm{O}_{1}=\text { nilai pretest }(\text { sebelum diberi perlakuan) } \\
& \mathrm{O}_{2}=\text { nilai posttest } \text { (setelah diberi perlakuan) }
\end{aligned}
$$

Pengaruh perlakuan terhadap prestasi kerja siswa $=\left(\mathrm{O}_{2}-\mathrm{O}_{1}\right)($ Sugiyono, $2017: 110-111)$.

Penelitian dengan judul "Efektivitas Pembelajaran Matematika melalui Penerapa ModelMeans - Ends Analysis(MEA) pada Siswa Kelas VIII SMP Negeri 1 Libureng Kabupaten Bone" dilakukan di SMP Negeri 1 Libureng yang beralamat di lingkungan Camming, Kelurahan Ceppaga, Kecamatan Libureng, Kabupaten Bone pada tahun ajaran 2018/2019. Populasi dalam penelitian ini adalah seluruh siswa kelas VIII SMP Negeri 1 Libureng Kabupaten Bone pada tahun ajaran 2018/2019 yang terdiri dari 5 kelas.Penempatan siswa kelas VIII dilakukan secara merata baik dalam hal kemampuan maupun kurikulum, sehingga dapat dikatakan bahwa karakteristik setiap kelas adalah homogen. Teknik pemilihan sampel menggunakan Cluster Random Sampling yaitu dengan mengambil satu kelas secara acak dari 5 kelas yang memiliki karakteristik yang sama. Dalam hal ini, kelompok sampel hanya terdiri dari kelompok eksperimen. 
Instrumen penelitian adalah alat yang digunakan untuk mengumpulkan data penelitian. Instrument penelitian yang digunakan pada penelitian ini adalah jenis instrument tes dan non tes yang terdiri dari:

\section{Tes Hasil Belajar Matematika Siswa}

Tes hasil belajar siswa dimaksud untuk mengetahui tingkat penguasaan siswa terhadap materi yang telah diajarkan dengan menggunakan Model MEA.

\section{Lembar Observasi Aktivitas Siswa}

Instrument ini dugunakan untuk memperoleh data tentang aktivitas siswa selama proses pembelajaran matematika dengan menggunakan Model MEA berlangsung. Pengambilan data aktivitas siswa dilakukan pada saat proses pembelajaran berlangsung yang dilakukan oleh dua orang observer, yaitu guru matematika yang berkualifikasi S1 pendidikan matematika dan satunya lagi berasal dari mahasiswa jurusan pendidikan matematika, lembar observasi ini sebagai bukti bahwa peneliti betul melakukan penelitian.

\section{Angket Respon Siswa}

Angket respon siswa digunakan untuk mengetahui respon siswa setelah pembelajaran dengan Model MEA.

Teknik analisis data pada penelitian ini adalah statistik deskriptis yang digunakan untuk menganalisis data dengan cara mendeksripsikan atau menggambarkan data yang telah berkumpul sebagaimana adanya tanpa bermaksud membuat kesimpulan yang berlaku untuk umum atau generalisasi.

a. Analisis Data Hasil Belajar Matematika

Hasil belajar siswa dianalisis dengan menggunkan analisis statistikdeskriptif dengan tujuan mendeskripsikan pemahaman materi matematika siswa setelah diterapkan Model MEA. Data hasil belajar matematika siswa yang digambarkan mengenai nilai rata - rata, nilai maksimum, nilai minimum dan standar deviasi.Hasil belajar siswa juga diarahkan pada pencapaian hasil belajar secara individual. Kriteria seorang siswa dikatakan tuntas belajar apabila apabila memiliki nilai paling sedikit 75 sesuai target ketuntas nasional dan KKM yang ditetapkan oleh pihak sekolah.Sedangkan ketuntasan klasikal tercapai apabila melebihi $80 \%$ siswa dikelas tersebut telah mencapai nilai Kriteria Ketuntasan Minimal (KKM).

Tabel 1. Kriteria Ketuntasan Minimal (KKM)

\begin{tabular}{cc}
\hline Nilai & Kategori \\
\hline $0 \leq \mathrm{x}<75$ & Tidak Tuntas \\
$75 \leq \mathrm{x} \leq 100$ & Tuntas \\
\hline Sumber: SMP Negeri 1 LIbureng (2018)
\end{tabular}


Sedangkan rumus ketuntasan secara klasikal adalah sebagai berikut:

$$
\text { Ketuntasan belajar klasikal }=\frac{\text { banyaknya siswa dengan skor } \geq 75}{\text { banyaknya seluruh siswa }} \times 100 \%
$$

Kriteria yang digunakan untuk menentukan kategori hasil belajar matematika adalah berdasarkan teknik kategorisasi yang ditetapan oleh Departemen Pendidikan Nasional sebagai berikut:

Tabel 2. Kategori Hasil Belajar Siswa

\begin{tabular}{cc}
\hline Interval Nilai & Kategori \\
\hline $0 \leq x \leq 54$ & Sangat Rendah \\
$54<x \leq 74$ & Rendah \\
$74<x \leq 84$ & Sedang \\
$84<x \leq 94$ & Tinggi \\
$94<x \leq 100$ & Sangat tinggi \\
\hline
\end{tabular}

Sumber: (Tahirman, 2013)

b. Analisis Data Peningkatan Hasil Belajar Siswa

Analisis deskriptif digunakan untuk mengetahui gain (peningkatan) hasil belajar matematika siswa pada kelas eksperimen. Gain diperoleh dengancara membandingkan hasil pretest dengan hasil posttest.Gainyang digunakan untuk menghitung peningkatan hasil belajar matematika siswa adalah gain ternormalisasi (normalisasi gain).

Adapun rumus N-gain ternormalisasi yaitu sebagai berikut:

$$
\mathrm{N} \text {-gain }=\frac{\text { Skor posttes }- \text { skor pretest }}{\text { SMI-Skor postest }}
$$

Untuk klasifikasi gain ternormalisasi terlihat pada table berikut:

Tabel 3. KriteriaNilai N-Gain

\begin{tabular}{cc}
\hline Nilai N-Gain & Kategori \\
\hline $\mathrm{N}$-Gain $\geq 0,70$ & Tinggi \\
$0,30<\mathrm{N}-$ Gain $<0,70$ & Sedang \\
$\mathrm{N}$-Gain $\leq 0,30$ & Rendah \\
\hline \multicolumn{2}{c}{ Sumber: Lestari \& Yudhanegara 2015:235 }
\end{tabular}

c. Analisis Data Aktivitas Siswa

Analisis data aktivitas siswa dilakukan dengan menentukan persentase frekuensi yang dilakukan oleh siswa dalam pembelajaran matematika dengan menggunakan model MEA. Data mengenai aktivitas siswa dianalisis dengan menghitung persentase tiap aktivitas siswa dengan menggunakan rumus:

$$
\mathrm{S}=\frac{\mathrm{X}}{\mathrm{N}} \times 100 \%
$$


Keterangan :

S : Persentase aktivitas siswa

$\mathrm{X}$ : Banyaknya siswa yang aktif/pasif setiap pertemuan

$\mathrm{N}$ : Jumlah siswa yang hadir setiap pertemuan

Indikator keberhasilanaktivitas siswa dalam penelitian ini ditunjukkan dengan sekurang kurangnya $75 \%$ siswa terlibat aktif dalam proses pembelajaran.

\section{d. Analisis Data Respon Siswa}

Data respon siswa yang telah dikumpul, selanjutnya dianalisis dengan mencari persentase jawaban siswa untuk tiap-tiap pertanyaan dalam angket.Respon siswa dianalisis dengan melihat presentase dari respons siswa. Persentase ini dapat dihitung dengan menggunakan rumus:

$$
P=\frac{\mathrm{f}}{\mathrm{N}} \times 100 \%
$$

Sumber : Nuratika (2015)

Keterangan:

$\mathrm{P}=$ Presentase respons siswa yang menjawab ya dan tidak

$f=$ Frekuensi siswa yang menjawab ya dan tidak

$\mathrm{N}=$ Banyaknya siswa yang mengisi angket

Kriteria yang ditetapkan untuk mengatakan bahwa para siswa memiliki respon positif terhadap pembelajaran matematika dengan model MEA adalah lebih dari atau sama dengan 75\% dari mereka memberi respon positif dari jumlah aspek yang ditanyakan.

\section{Hasil dan Pembahasan}

Berikut ini akan diuraikan hasil analisis statistik deskriptif yaitu tentang efektivitas pembelajaran matematika dengan penerapan model Means - Ends - Analysis (MEA). Adapun indikator keefektifan yang akan dijabarkan yaitu mengenai hasil belajar matematika siswa sebelum dan setelah penerapan model MEA, hasil obeservasi aktivitas siswa, dan hasil angket respon siswa terhadap pembelajaran matematika melalui penerapan MEA. Deskripsi masing masing hasil analisis tersebut diuraikan sebagai berikut:

a. Deskripsi Hasil Belajar Matematika Siswa

Data hasil belajar matematika siswa kelas VIII A SMP Negeri 1 Libureng sebelum diterapkan model MEA dapat dilihat pada tabel 4 berikut ini. 
Tabel 4. Distribusi Frekuensi dan Persentase Skor Pre - Test Siswa

\begin{tabular}{cccc}
\hline Skor & Kategori & Frekuensi & Persentase (\%) \\
\hline $0 \leq x<55$ & Sangat Rendah & 26 & 100 \\
$55 \leq x<75$ & Rendah & - & - \\
$75 \leq x<85$ & Sedang & - & - \\
$85 \leq x<95$ & Tinggi & - & - \\
$95 \leq x \leq 100$ & Sangat tinggi & - & 100 \\
& Jumlah & $\mathbf{2 6}$ & Sumber : (Hasil olah data)
\end{tabular}

Pada tabel 4 diatas ditunjukkan bahwa dari 26 siswa kelas VIII A SMP Negeri 1 Libureng, semua siswa memperoleh skor pada interval nilai $0 \leq x<55$ yang berarti berada dalam kategori sangat rendah, dan tidak ada siswa yang memperoleh skor pada interval nilai $55 \leq x<75,75 \leq x<85$, dan $85 \leq x<95$, serta $95 \leq x \leq 100$ yang berarti bahwa tidak terdapat siswa yang skornya berada dalam kategori rendah, sedang, dan tinggi serta sangat tinggi. Setelah skor rata - rata hasil belajar matematika siswa sebesar 18.57 dikonveksi ke dalam 5 kategori di atas, maka nilai rata - rata hasil belajar matematika siswa kelas VIII A SMP Negeri 1 Libureng sebelum diajar dengan penerapan model MEA secara umum berada pada kategori sangat rendah.

Data hasil belajar matematika siswa setelah diterapkan model MEA dapat dilihat pada tabel 5 berikut ini.

Tabel 5. Distribusi Frekuensi dan Persentase SkorPost - Test Siswa

\begin{tabular}{cccc}
\hline \multicolumn{1}{c}{ Skor } & Kategori & Frekuensi & Persentase (\%) \\
\hline $0 \leq x<55$ & Sangat Rendah & 0 & 0 \\
$55 \leq x<75$ & Rendah & 4 & 15.4 \\
$75 \leq x<85$ & Sedang & 17 & 65.4 \\
$85 \leq x<95$ & Tinggi & 5 & 19.2 \\
$95 \leq x \leq 100$ & Sangat tinggi & 0 & 0 \\
& Jumlah & $\mathbf{2 6}$ & $\mathbf{1 0 0}$ \\
\hline & & Sumber : (Hasil olah data lampiran)
\end{tabular}

Pada tabel 5 diatas ditunjukkan bahwa dari 26 siswa kelas VIII A SMP Negeri 1 Libureng tidak terdapat siswa $(0 \%)$ yang memperoleh skor pada interval nilai $0 \leq x<55$ yang berarti dalam kategori sangat rendah, 4orang siswa (15.4\%)yang memperoleh skor pada interval nilai $55 \leq x<75$ yang berarti dalam kategori rendah, 17 orang (65.4\%) yang memperoleh skor pada interval nilai $75 \leq x<85$ yang berarti dalam kategori sedang,5 orang (19.2\%) yang memperoleh skor pada interval nilai $85 \leq x<95$ yang berarti dalam kategori tinggi, dan tidak terdapat siswa $(0 \%)$ yang memperoleh skor pada interval nilai $95 \leq x \leq 100$ 
yang berarti dalam kategori sangat tinggi. Setelah skor rata-rata hasil belajar siswa sebesar 80.23 dikonversi kedalam 5 kategori diatas, maka skor rata-rata hasil belajar matematika siswa kelas VIII A SMP Negeri 1 Liburengsetelah diajar dengan menerapkan model MEA secara umum berada pada kategori sedang.

Kemudian untuk melihat persentase ketuntasan hasil belajar matematika siswa sebelum penerapan model MEA dapat dilihat pada tabel 6 berikut ini.

\begin{tabular}{|c|c|c|c|}
\hline Interval Nilai & Kategori & Frekuensi & Persentase (\%) \\
\hline $0 \leq \mathrm{x}<75$ & Tidak Tuntas & 4 & 15,4 \\
\hline $75 \leq x \leq 100$ & Tuntas & 22 & 84,6 \\
\hline \multicolumn{2}{|c|}{ Jumlah } & 26 & 100 \\
\hline
\end{tabular}

Kriteria seorang siswa dikatakan tuntas belajar apabila memiliki nilai paling sedikit 75, sedangkan ketuntasan klasikal tercapai apabila $80 \%$ siswa di kelas tersebut telah mencapai skor paling sedikit 75. Dari tabel 4.6 diatas menunjukan bahwa jumlah siswa yang tidak memenuhi kriteria ketuntasan adalah sebanyak 4 orang dengan persentase $15.4 \%$ dari jumlah siswa, sedangkan siswa yang memenuhi kriteria ketuntasan adalah sebanyak 22 orang dengan persentase $84.6 \%$. Dengan kata lain secara umum siswa kelas VIII A SMP Negeri 1 Libureng memenuhi Kriteria Ketuntasan Minimal (KKM = 75). Berdasarkan deskripsi di atas dapat disimpulkan bahwa hasil belajar matematika siswa kelas VIII A SMP Negeri 1 Libureng sebelum penerapan model MEA tidak memenuhi kriteria ketuntasan secara klasikal.

b. Deskripsi Peningkatan Hasil Belajar Matematika Siswa setelah Diterapkan Model MEA

Data pre - test dan post - test siswa selanjutnya dihitung dengan menggunakan rumus Normalized Gain. Tujuannya adalah untuk mengetahui seberapa besar peningkatan hasil belajar siswa kelas VIII A SMP Negeri 1 Libureng setelah diterapkan model MEA pada pembelajaran matematika. Hasil pengolahan data yang telah dilakukan (lampiran III) menunjukkan bahwa hasil Normalized Gainatau rata-rata gain ternormalisasi siswa setelah diajar dengan menerapkan model MEA adalah 0.7577 . Untuk melihat persentase peningkatan hasil belajar siswa dapat dilihat pada Tabel 7 berikut:

Tabel 7. Kriteria Tingkat Gain Ternormalisasi

\begin{tabular}{cccc}
\hline Nilai N-Gain & Kategori & Frekuesi & Persentase $(\%)$ \\
\hline N-gain $\geq \mathbf{0 . 7}$ & Tinggi & 21 & 80.77 \\
$\mathbf{0 . 3}<\mathbf{N}$-gain $<\mathbf{0 . 7}$ & Sedang & 5 & 19.23 \\
N-gain $\leq \mathbf{0 . 3}$ & Rendah & 0 & 0 \\
Jumlah & & $\mathbf{2 6}$ & $\mathbf{1 0 0}$ \\
\hline
\end{tabular}


Berdasarkan tabel 7 diatas dapat dilihat bahwa sebanyak 21 siswa $(80.77 \%)$ yang nilai gainnya berada dalam interval $\mathrm{N}$-gain $\geq 0,70$ yang artinya peningkatan hasil belajarnya berada pada kategori tinggi dan 5 siswa (19.23\%) nilai gainnya berada pada interval $0,3<\mathrm{N}$-gain $<$ 0,7 yang artinya peningkatan hasil belajarnya berada pada kategori sedang, serta tidak terdapat siswa $(0 \%)$ yang nilai gainnya berada pada interval $\mathrm{N}$-gain $\leq 0,3$ yang berarti peningkatan hasil belajarnya berada dalam kategori rendah.

c. Deskripsi Hasil Pengamatan Aktivitas Siswa dalam Mengikuti Pembelajaran

Secara umum hasil analisi data aktivitas siswa tersebut menunjukkan aktivitas siswa yang berada pada ketogori aktivitas positif atau aktif yaitu dengan rata - rata $86.05 \%$ sedangkan yang berada pada kategori aktivitas negatif dengan rata - rata 3.845\%.

d. Deskripsi Respon Siswa terhadap Pembelajaran dengan Model MEA

Secara umum rata-rata siswa kelas VIII A SMP Negeri 1Libureng memberikan respon positif terhadap proses pembelajaran melalui penerapan model MEA, dimana rata-rata persentase respons siswa adalah77.5\%. Dengan demikian respon siswa dapat dikatakan efektif karena telah memnuhi kriteria respon siswa yakni $\geq 75 \%$ memberikan respon positif.

\section{Simpulan dan Saran}

Adapun kesimpulan yang dapat diambil dari hasil penelitian adalah pembelajaran matematika efektif melalui penerapan model MEA. Hal tersebut dapat dilhat dari hasil analisis dari ketiga indikator yang dijadikan sebagai acuan keefektifan pembelajaran pada penelitaian ini. Adapun ketiga indikator tersebut sebagai berikut sebagai berikut: 1) Ketuntasan hasil belajar siswa, dari hasil analisis deskriptif menunjukkan bahwa hasil belajar matematika siswa setelah penerapan model MEA dalam pembelajaran matematika termasuk dalam kategori tinggi dengan nilai rata - rata 80.23. Hasil ini juga menunjukkan bahwa trdapat 22 siswa atau 84,6\% yang mencapai KKM dan 4 siswa atau 15,4\% yang tidak mencapai KKM (mendapat nilai dibawah 75) sehingga dapat dikatakan bahwa hasil belajar siswa telah mencapai kriteria ketuntasan secara klasikal. 2) Rata - rata dari komponen penilai aktivitas siswa dalam pembelajaran matematikan dengan penerapan model MEA berada dalam ketegori aktif dengan rata - rata 86.06\%, dan 3) Respon siswa terhadap pembelajaran matematika dengan penerapan model MEA dikategorikan potitif dengan persentase $78 \%$.

Berdasarkan kesimpulan yag diperoleh dari penelitian ini, maka peneliti mengajukan beberapa saran sebagai beikut: 1) Kepada peneliti yang akan melakukan penelitian dengan menerapkan model MEA diharapkan dapat menguasai materi pembelajaran sebelum 
pembelajaran dimulai, dan 2) Keberhasilan peneliti pada model MEA hanya pada matei elasi dan fungsi sehingga dihaapkan pada peneliti yang ingin melakukan penelitian dengan model MEA agar meneapkannya pada meteri yang lain agar kita dapat mengetahui bersama materi apa saja yang cocok dengan model MEA.

\section{Referensi}

Himitsuqalbu. 2015. Defenisi Hasil Belajar Menurut Para Ahli, (Online), (http://himitsuqalbu.wordpress.com/2015/05/13/defenisi-hasil-belajar-menurut-paraahli/) di akses pada tanggal 12 Januari 2018 pada pukul 19:04 WITA

Huda, Miftahul. 2016. Model - Model Pengajaran dan Pembelajaran. Yogyakarta: Pustaka Pelajar.

Joebagio, Hermanu, dkk. 2017. The Development of Means - Ends Analysis and Value Clarifications Technique Integration Model to Explore The Local Wisdom in Historical Learning. Journal of Education and Learning. Vol. 11(2)pp. 179 - 187

Nuratika, Fildzah. 2015. Efektivitas Pembelajaran Matematika melalui Pendekatan Problem Posing Setting Kooperatif pada Siswa Kelas VII SMP Negeri 1 Sunguminasa.Skripsi tidak diterbitkan.Makassar. Unismuh Makassar.

Sugiyono. 2017. Metode Penelitian Pendidikan (Pendekatan Kuantitatif, Kualitatif, danR\&D). Bandung: Alfabeta.

Tahirman, Warni. 2013. Efektivitas Pembelajaran Matematika Melalui Penerapan Pendekatan Open Ended Problem pada Siswa Kelas VIII SMP Negeri 1 Larompong Kabupaten Luwu. Skripsi tidak diterbitkan. Makassar: FKIP Unismuh Makassar.

Trianto. 2009. Mendesain Model Pembelajaran Inovatif Progresif. Surabaya: Kencana

Uno, Hamzah B., dan Nurdin Mohammad. 2014. Belajar Dengan Pendekatan PAKEM. Jakarta : Bumi Aksara. 